\title{
Transforming Islamic Law in Indonesia from a Legal Political Perspective
}

\author{
Ahmad Yani ${ }^{1}$ Megawati Barthos $^{2}$ \\ ${ }^{1}$ Program Doktor Ilmu Hukum Universitas Borobudur, Jakarta-Indonesia ${ }^{2}$ Universitas \\ Borobudur, Jakarta-Indonesia \\ 1ayhasyimlaw@gmail.com, ${ }^{2}$ megawati_barthos@borobudur.ac.id
}

\begin{abstract}
This article aims to discuss the transformation of Islamic law in Indonesia. This research is qualitative in the form of a literature study with a political-law approach. The idea of this paper is based on a misunderstanding of Islamic law and Islamic law and figh. Issues related to the debate on the application of Islamic law in the contemporary era also contribute to thoughts in this paper. This paper concludes that the transformation of Islamic law into national law is a difficult task. This is because Indonesia is a multi-cultural, multi-ethnic, and multi-religious country. The most important reason is due to the variety of Muslim understanding of religious texts
\end{abstract}

Keywords: transformation; Islamic law; fiqh; Islamic legal politics

\section{]}

Artikel ini bertujuan untuk mendiskusikan tentang transformasi hukum Islam di Indonesia. Penelitian ini bersifat kualitatif berupa studi kepustakaan dengan pendekatan politik hukum. Ide tulisan ini didasari pada salah kaprahnya pemahaman terkait hukum Islam dengan syariat Islam dan figh. Hal terkait perdebatan penerapan hukum Islam di masa kontemporer juga menjadi sumbangan pikiran dalam tulisan ini. Tulisan ini menyimpulkan bahwa transformasi hukum Islam ke dalam hukum nasional merupakan suatu pekerjaan yang tidak mudah. Hal ini disebabkan Indonesia merupakan negara multi kultural, multi etnis, dan multi agama. Adapun alasan yang paling utama yaitu karena variatifnya pemahaman umat Islam terhadap teks keagamaan.

Kata Kunci: transformasi; hukum Islam; fiqh; politik hukum Islam 
Ahmad Yani, Megawati Barthos

\section{Introduction}

Islam is a religion that is embraced by the majority of the Indonesian population, of course, this will greatly affect the lifestyle of the Indonesian nation. From the perspective of the Indonesian people, Islamic law is an important part of religious teachings and in Islam, the room of expression becomes the main experience and becomes the determination of continuity and historical identity.

Islamic law in Indonesia, in a very simple formulation, can be stated as legal norms derived from Islamic law which grew and developed in people's lives throughout the landscape of Indonesian history. He was born from the result of a normative marriage (Sharia) with Indonesian local contents as a whole. ${ }^{1}$

Islamic law can be understood as a law that comes from the teachings of Islamic law, namely the Qur'an and the Sunnah. In simple terms, the law can be understood as a set of rules or norms that regulate human behavior in a society, whether the rules or norms are in the form of a reality that grows and develops in society or a provision set by the authorities.

According to Muhamad Daud Ali, there are two kinds of the Islamic law that apply in Indonesia, namely normative and formal juridical. Islamic law that applies normatively is a part of the Islamic law that has social sanctions if those norms are violated. The strength of the sanctions depends on the strength of the awareness of the Muslim community, aka the normative norms. Islamic law that is normative includes prayer, fasting, zakat, and hajj. ${ }^{2}$

Islamic law is formal juridical, which is related to muamalah aspects, especially in the civil sector, some of which have become part of positive law in Indonesia, where the process of transitioning to positive law must be based on laws and regulations, for example, marriage law, inheritance law, and waqf law which has been compiled into civil law in Indonesia. ${ }^{3}$ Islamic law as one of the raw materials in the development of national law is required to be able to play a role and compete with other laws. The appropriate application of Islamic law in

\footnotetext{
${ }^{1}$ Ali Imron, 'Transformasi Hukum Islam ke dalam Hukum Nasional Indonesia', Jurnal Hukum dan Dinamika Masyarakat Vol.5 No.2 April 5, no. 0854 (2008): 130.

2 Hamdan Zoelva, 'Relasi Islam, Negara, dan Pancasila dalam Perspektif Tata Hukum Indonesia', Journal de Jure 4, no. 2 (2012): 99-112, https://doi.org/10.18860/j-fsh.v4i2.2980.

3 Zoelva.
} 
Indonesia, according to the author, is to transform Islamic legal principles into the Indonesian national legal system.

The social problem of the enactment of Islamic law identity arises when the formulation of the Basic State as stated in the Jakarta Charter dated June 22, 1945. The basic formulation of the Indonesian state is "A country that is based on Divinity by implementing Islamic Sharia for its adherents". However, the reason for the plurality of religions in Indonesia that ultimately required Muslims to give up the basic formula in the Jakarta Charter was changed to "Belief in the one and only God".

According to Hazairin, the change in the word in the Jakarta Charter to become "God Almighty" contains Legal Norms stipulated in Article 29 paragraph (1) of the 1945 Constitution that the Republic of Indonesia is based on one supreme deity. This can only be interpreted, among other things: "Muslims are obliged to carry out the teachings of Islamic Sharia, just as other religions are obliged to carry out their religion". Another interpretation is that "religious teachings do not require the assistance of state power to carry them out because it is a personal obligation towards their respective religions".4

Islamic law has a broader scope than national law. Some of its provisions do not require state powers to enforce and others do not. Thus, not all provisions of Islamic law need to be legalized. ${ }^{5}$ General provisions related to Islamic law that need to be legalized are legal provisions that have categories: enforcement requires the assistance of state powers and correlates with public order. ${ }^{6}$ This study uses a qualitative method with a literature study approach. By mapping the debates and discussions related to the politics of Islamic law and the transformation of Islamic law in Indonesia which is the subject of this paper.7

\footnotetext{
4 Norcahyono Norcahyono, 'Problematika Sosial Penerapan Hukum Islam di Indonesia', JURIS Ournal Ilmiah Syariah) 18, no. 1 (2019): 23, https://doi.org/10.31958/juris.v18i1.1399.

5 Imron, 'Transformasi Hukum Islam ke dalam Hukum Nasional Indonesia', 130.

6 Jazuni, Legislasi Hukum Islam di Indonesia (Bandung: Citra Aditya Bakti, 2005), 353.

${ }^{7}$ Ahmad Zuhdi, 'Perkembangan Metodologi Penelitian Hukum', Jurnal Hukum dan Peradilan, 1, no. 2 (2012): 189-206.
} 


\section{Islamic Law Thought in Indonesia}

Often, we misunderstand the differences in detail between Islamic law and fiqh. ${ }^{8}$ It is important to understand that these three words, in the Indonesian context, are often used to equate their meanings without the slightest distinction. Even though in the academic context there are still differences in the three words.

On this occasion, the author discussed to explain the differences between the three briefly and simply. "Islamic Sharia" is the main source of fiqh, namely legal texts that are still listed in the Qur'an and Hadìth, which are usually called la yanțiq (cannot state anything) unless stated reasonably by humans (understood) as operational provisions. Meanwhile, "fiqh" is the result of the ulama's understanding of the legal texts contained in the Qur'an and Hadith (called Islamic shari'a). As a knowledge, fiqh can be true, it can also be wrong, and it often differs from one scholar to another. ${ }^{9}$

Islamic law or fiqh in Indonesian is usually translated as Islamic law. They are two different things. Islamic law in the Indonesian context is often understood as a set of legal rules originating from Islam, namely the Koran, sunnah, ijmā ', and qiyās. If this is what is meant, of course, Islamic law is fiqh. Apart from fiqh, there is also qaḍa 'which is also often referred to as Islamic law. Besides, there are also fatwas as a product of fiqh. ${ }^{10}$

In the context of the explanation above, Islamic law has two dimensions, namely the theological dimension as part of the Muslim understanding of the revelation texts contained in the Qur'an and sunnah. Although it has a theological dimension, Islamic law remains a part. Then the second is the sociological dimension as part of the efforts of Muslims to realize justice, benefit, and humanity in human life. ${ }^{11}$

In the context of Indonesia, Islamic law, like other religions, is a source of inspiration and a source of ethics for legal development in Indonesia. Because

\footnotetext{
8 Maskur Rosyid, Implementasi Konsep Maslahat Al-Tüfi dalam Fatwa MUI (2005-2010), 1st ed. (Magelang: Ngudi Ilmu, 2013), 1.

9 Said Aqil Siraj, Islam Sumber Inspirasi Budaya Nusantara (Jakarta: LTN NU, 2015), 111-12.

10 Maskur Rosyid and M. Nurul Irfan, 'Reading Fatwas of MUI a Perspective of Maslahah Concept', Syariah:Jurnal Hukum Dan Pemikiran 19, no. 1 (2 June 2019): 91-92.

11 Ṭāhā Jābir Al-Alwānī, Source Methodology In Islamic Jurisprudence, ed. Yusdani (Yogyakarta: UII Press, 2001), 4; Rosyid, Implementasi Konsep Maslahat Al-Ṭüfi Dalam Fatwa MUI (2005-2010), 1.
} 
the Indonesian state is a Pancasila state and the legal development on the agenda is a national law, the position of Islamic law is equal and equal to other laws recognized in the Indonesian legal system.

Fiqh in the Indonesian context, which is a struggle from the existing school of thought with the Indonesian socio-cultural context, so that the existing figh is truly integrated into national law, just a further step. Ușūl fiqh science itself is a set of standard methods used by Islamic thinkers in exploring Islamic law and other fields. Today Islamic fiq $h$ is considered barren because of the rhetoric role of ușül fiqh science which is considered less relevant to address contemporary problems such as human rights issues, pluralism, gender equality, football, and women's boxing, as well as problems arising from biotechnological engineering such as organ transplants. body, sperm graft, sperm bank, and so on. ${ }^{12}$

\section{Transformation of Islamic Law in Indonesia}

Transforming Islamic law in the context of the Unitary State of the Republic of Indonesia has various meanings and conceptions. The word transformation itself has the meaning of changing appearance, diverting, changing the basic structure into another structure by applying the transformation rules. ${ }^{13}$ In terms of the conception of Islamic law which is transferred to Indonesian national law. By transforming the conception of Islamic law into national law, the substance of Islamic law in terms of enriching national law is equivalent to other laws recognized in this country.

Jaih Mubarok argues that one form of Islamic legal thought is qānūn or statutory regulations. The penetration of Islamic law into statutory regulations in Indonesia can be divided into two, namely first, the penetration of Islamic law into statutory regulations in a substantive manner and not explicitly stated as

\footnotetext{
12 According to Abdillahi Ahmed al-Na'im, this is due to difficulties in combining classical and contemporary fiqh thought patterns in several matters, including those relating to public law, modern constitutionalism, criminal law, modern international law and human rights. human. Read; Abdullahi Ahmed Al-Na'im, Toward an Islamic Reformation: Civil Liberties, Human Rights and International Law (New York: Syracusse University Press, 1990).

13 Departemen Pendidikan Nasional, Kamus Besar Bahasa Indonesia Pusat Bahasa (Jakarta: Gramedia Pustaka Utama, 2008), 1209.
} 
Islamic laws. Second, the transformation of Islamic law into legislation which is explicitly stated as Islamic law. ${ }^{14}$

The application of Islamic law in the first model is more by the culture and spirit of the objectives of the Unitary State of the Republic of Indonesia (NKRI) as stated in the preamble to the 1945 Constitution. Therefore, transforming the principles of Islamic law occupies a strategic position, compared to the demands of Islamic law which legal formalistic. ${ }^{15}$

The word principle itself comes from Arabic which means basis and foundation in the original language $a s \bar{a} s$. The word principle itself is a basic meaning or something on which to think, is basic or principal, ideals, and basic law. ${ }^{16}$ The word principle also has the meaning of (1) basic, foundation, (2) truth which is the focus of thinking or opinion, and (3) ideals on which the organization or state is based. ${ }^{17}$ Legal principles are legal ideals; the substance of the maqāsid sharīa (the purpose of which is the law). Existing laws and regulations must not come out of their legal principles. A legal system that will be built without legal principles will only be a pile of laws with no direction and no clear purpose. 18

The principles of Islamic law come from the source of Islamic law, namely the Qur'an and the sunnah which were developed by the minds of people who qualify for ijtihād.19 Interpretation of these principles must be done holistically by emphasizing the benefits aspects. The narrow interpretation of legal principles, according to Yusriyadi, will result in a shift in interpretation that violates human rights. ${ }^{20}$

The principles of Islamic law have been outlined by Allah in the text, both expressly and implicitly. The principles of the Islamic law that are common in

\footnotetext{
14 Jaih Mubarok, 'Dinamika Pemikiran Hukum Islam di Indonesia', Jurnal Unusia UII Yogyakarta II, no. 48 (2003): 116-17.

15 Imron, 'Transformasi Hukum Islam ke dalam Hukum Nasional Indonesia', 131.

16 Imron, 70.

17 Departemen Pendidikan Nasional, Kamus Besar Bahasa Indonesia Pusat Bahasa, 60.

18 Sarjito Raharjo, Sisi-Sisi Lain dari Hukum di Indonesia (Jakarta: Penerbit Buku Kompas, 2003), 140.

${ }^{19}$ Ahmad Hanafi, Asas-Asas Hukum Pidana Islam (Jakarta: Bulan Bintang, 1990),37-55.

20 Yusriadi, 'Strategi Pembangunan Nasional Bidang Hukum Era Orde Baru (Analisis Teoritik Tentang Kebijakan dan Implikasinya Terhadap Penyelenggaraan Hukum di Indonesia)', MasalahMasalah Hukum2, no. Januari-Maret (2000): 62.
} 
law (general) and coloring or applicable in Indonesia include, among others, the principle of justice, the principle of expediency, the principle of legal certainty, the principle of legality, the principle of responsibility (criminal) is borne alone and cannot be represented or transferred to anyone. other, the principle of the presumption of innocence, the principle of worship or permissibility (civil), the principle of mașlaha (the best interests of the parties), the principle of prioritizing obligations and ending rights, the principle of freedom in doing business (civil), the principle of social functioning rights (civil), the principle of protection for those in good faith, as well as the principle of proof in writing and testimony (civil).

There are several principles of the Islamic law that still need further study and can be transformed into national law. Some of them are the principle of fahm al-mukallaf, the principle of criminal forgiveness by the victim or the victim's family, and the principle of not retroactive. The principle of fahm almukallaf is the understanding or knowledge of the perpetrator of the content or substance of the law which becomes a prerequisite for legal accountability. Even though there are legal regulations and it is also proven that the perpetrator is guilty, the perpetrator is not necessarily subject to legal sanctions. To be able to understand the contents of these regulations first.

In this case, Lon L. Fuller quoted by Satjipto Rahardo said that legal regulations that were not conveyed properly to the people made the legal system immoral. The sentences used in these regulations must also be clear and easily understood by the people. ${ }^{21}$ Furthermore, so that the complete contents of regulation are notified to every member of the community who later must accept the enactment of the law.

The requirements for legal (criminal) liability are identical to the requirements for conviction (imposition of a crime or act). This means that the principles of criminal responsibility are also identical with the principles of punishment in general, namely the principles of legality and the principle of culpability. It can even be stated that the criminal liability system in a broad sense cannot be separated from the whole system (rules) of punishment.22 This

21 Satjipto Raharjo, Hukum Masyarakat dan Pembangunan (Bandung: Alumni, 1980), 201.

22 Muhammad Afdilah, Dari Masjid ke Panggung Politik: Melacak Akar-Akar Kekerasan Agama Antara Komunitas Sunni dan Syiah di Sampang, Jawa Timur (CRCSUniversitas Gadjah Mada, 2016), 57. 
provision is different from the provisions contained in Islamic law. Apart from these principles of legality and culpability, the fahm al-mukallaf principle is still required.

The existence of criminal liability, in the current prevailing law in Indonesia, first of all, must be met with objective requirements, namely that the act must be a criminal act according to the applicable law. In other words, for the existence of criminal responsibility, the principle of legality must first be fulfilled, namely that there must be a clear legal basis or source (legitimacy) both in the field of material criminal law and formal criminal law. Regarding the provisions of the principle of legality, this is in line with the word of Allah Surah Al-Isrä' (17) verse 15 which means "and a sinner cannot carry the sins of others, and We will not punish (punish) before We send an apostle". The verse explains that Allah will not punish except after sending an apostle to explain the punishment.

To transform Islamic law in Indonesia itself, it has encountered many obstacles, of course, it is natural and a logical consequence of reform efforts. There are 3 (three) obstacles in transformation, namely: Normative constraints originate from variations in the understanding of Muslims towards the Islamic text itself. Then the sociological obstacle is that not all Muslims in Indonesia have the same sect so that their patterns of thinking are also different because the references are of course different. The last obstacle is a political obstacle, Indonesia which is a pluralistic country, often appears the impression that the privilege of Islamic law for Muslims will of course be a problem for other people.

Even so, the obstacles to the transformation of Islamic law today are mostly caused by external influences, namely the entry of transnational Islamic ideologies and ideas, for example, hizbut tahrir and several Islamic organizations that tend to be fundamentalists and allow terrorism as a way of jihad. If we look at the indigenous people and culture of Indonesia, they are very accommodating to Islamic values and teachings, including the Pancasila ideology which is the basis of the Indonesian state. The transformation of the Islamic law that has been taking place is supported by the original culture of Indonesia.

The transformation of Islamic law into Indonesian national law has been carried out by two approaches, namely a cultural approach and a political approach. The cultural approach is carried out through practicing Islamic 
teachings in a cultural context. This was later adopted by national law as part of the reality of Indonesian society. Then through a political approach, in which Islamic law is pushed to become national law through legislation and political lobbying. In other languages, it can be said to formalize Islamic law into laws, regional regulations, and others. This approach usually tends to prioritize Islamic symbols, rather than substance so that they seem exclusive in obtaining this privilege.

As has been discussed above, the transformation of Islamic law in Indonesia must certainly consider Indonesian society which is pluralistic, multi-cultural, and multi-sectarian. Transformation does not have to end in a formalization process but also an internalization process.

\section{Political Islamic Law in Indonesia}

Talking about the politics of Islamic law in Indonesia, of course, we need to carry out discussions related to legal policy in Indonesia. In the early days of the establishment of the Indonesian nation, which was previously conditioned to follow the Dutch legal system, began to break away and seek to explore the law independently. In this case, this does not mean changing it in a revolutionary manner as the acquisition of independence itself. Changing a legal product that has long been institutionalized in the patterns of national life is not easy. Persuasive efforts are required and must be carried out continuously, systematically, and simultaneously.

The efforts made by our founding fathers towards Islamic law were to apply the reception exit theory, which was Hazairin's idea, which meant rejecting the concept of the reception theory imposed by the previous Dutch colonial government. In the receptio theory, the Dutch colonial government deliberately created this concept to block the progress of Islam in Indonesia. This theory is the same as the devil theory. ${ }^{23}$ Because it invites Muslims to disobey and carry out the orders of Allah and His Messenger.

In the context of Islamic law in Indonesia, the relationship between state and religion is an important subject. Therefore, it can be seen periodically in history, namely in the pre and early days of independence, the old order, the new order,

${ }^{23}$ Atun Wardatun, 'Legitimasi Berlapis dan Negosiasi Dinamis pada Pembayaran Perkawinan Perspektif Pluralisme Hukum', Al-Ahkam 28, no. 2 (2018): 147-66. 
and the reform order. This debate has been going on for almost a century and continues to the present day but remains unsolved completely. 24

In the pre-independence era, the relationship between state and religion began with a discourse on the concept of nationality which also carried the idea of Islam as the basis of the state and other ideas requiring the enactment of the state and other laws rooted in the lives of the Indonesian people. ${ }^{25}$ Because of this, based on historical records the rise of Indonesian nationalism at this time was marked by the emergence of movements in this country fighting against Dutch colonialism. In this struggle, Islam has an important role in determining the existence of this country in the future, and historically there can be debates about whether an independent state will have an Islamic or non-Islamic ideology. ${ }^{26}$

First, in 1916 there was an uproar in the Jawi Hisworo newspaper, namely the political struggle between the struggle for a non-Islamic ideology against Islam. At that time, the Javanese language newspaper published insulting writings on the Prophet Muhammad by saying that he was a drunk and a convict which of course then aroused Muslims to defend their rights accompanied by the content of the idea that society needed to be regulated in an Islamic way, as stated through the Prophet Muhammad. This movement was intensively voiced by, among others, the Sarekat Islam.

Second, Soekarno and Natsir were having a polemic about Islam and the state. ${ }^{27}$ The polemic began with Soekarno's writing in the Islamic banner with the title "Menudakan Understanding of Islam". This paper was originally intended to respond to K.H. Mas Mansur, entitled "Paying attention to the Youth Movement" in Adil Magazine and Panji Islam. Soekarno's writing contained criticisms of the orthodoxy of Islam which he said needed to be corrected for his

${ }^{24}$ Abdul Halim, 'Membangun Teori Politik Hukum Islam di Indonesia', AHKAM: Jurnal Ilmu Syariah 13, no. 2 (2013): 259-70, https://doi.org/10.15408/ajis.v13i2.938.

25 Uswatun Hasanah, 'Perempuan dan Hak Asasi Manusia dalam Perspektif Hukum Islam', Jurnal Hukum \& Pembangunan 40, no. 4 (2010): 440, https://doi.org/10.21143/jhp.vol40.no4.235.

26 Muhammad Siddiq Armia, 'Sumbangsih Kerajaan Muslim Indonesia dalam Pengembangan Peradilan Islam: Analisis Historical Legal Approach', Jurnal Justicia: Jurnal Ilmu Hukum, PerundangUndangan dan Pranata Sosial 2, no. 2 (2017): 1-16, https://jurnal.ar-raniry.acid/index.php/ Justisia/article/view/2653/1906.

27 Eva Iryani, 'Hukum Islam, Demokrasi dan Hak Asasi Manusia', Jurnal Ilmiah Universitas BatanghariJambi 17, no. 2 (2017): 24-31. 
understanding. Soekarno invited the understanding and thought of Islam to always be renewed and not maintained conservatively. Because Islamic laws can always adapt to culture and development conditions and can match progress.

Third, the next experience is the formal debate at the Investigation Agency for Preparatory Efforts for Independence (BPUPKI) which was formed in April 1945, and the Preparatory Committee for Indonesian Independence (PPKI), a body formed to declare independence, transfer power, ratify the constitution, and form a government for Indonesia if it will become independent. ${ }^{28}$

This is where the climax of the conflict becomes clearer during the process of forming the foundation of the Republic of Indonesia. In addition to having existed before Japan came, this conflict model was the result of the divide et empera process carried out by Japan to strengthen its position. In other words, the tension between Islamic and nationalist groups became a class when Japan formed BPUPKI and its sessions when discussing the basis of the state, in the form of collaboration with several groups of the Indonesian nation. At that time, the Indonesian nation could at least be grouped into three groups, namely the nationalist elite, the priyayi elite, and the Islamic elite. ${ }^{29}$ In continuing the collaboration, these three groups were accommodated in turn. So since then, the political relationship between Islam and the state has become suspicious or antagonistic.

At the second plenary session, July 10-16, 1945, an agreement was reached based on the state and the state constitution, namely Piagam Jakarta dan UUD 1945 (Indonesian constitution). The Jakarta Charter (Piagam Jakarta) as outlined in the draft Mukadimah accommodates Islam as the basis of a special state for Muslims, which is included in the first precept with the sentence "Deity with the obligation to carry out Islamic law for its adherents".

Apartfrom its content which is not disputed, the compiler of the Mukadimah with the Jakarta Charter is explained by the two book sources differently. According to Yamin's statement, the Jakarta Charter was drafted by the

${ }^{28}$ Andi Alma Wardi Mulus, 'Reformasi Negara Konstitusi dan Demokrasi Menurut Pemikiran Prof. Dr. Moh. Mahfud MD' (UIN Sultam Maulana Hasanuddin Banten, 2018).

29 Eko Eddya Supriyanto, 'Kontribusi Pendidikan Pesantren Bagi Pendidikan Karakter di Indonesia', Jurnal Pendidikan NUsantara 1, no. 1 (2020): 13-26. 
Committee of Nine appointed by BPUPKI at the session on June 1, 1945,30 but according to AB Kusuma, it was stated that the Committee of Nine was never formed by BPUPKI. Instead, it was formed spontaneously and undocumented by Soekarno, because of the development of the World War II situation which was heating up at that time. AB Kusuma's opinion is based on the content of Bung Karno's speech himself apologizing to the BPUPKI session for the unprocedural gathering of 9 (nine) people to compile a draft of the Preamble to the Constitution by Ir. Soekarno was given the title "Mukadimah", by Yamin the name "Jakarta Charter", and by Dr. Sukiman is called the Gentlemen's Agreement because it is not yet a decision by BPUPKI. ${ }^{31}$

The struggle for political influence between the two camps, namely Islam and the nationalists, in this era looks tight. This can be seen in the debates at the sessions at BPUPKI / PPKI. The Islamic group stated that Indonesia must one day become an Islamic state or Islam becomes the state ideology. The nationalist group proposed the formation of a national unitary state.

In subsequent developments, the Islamic group split into two, namely the camp which still wanted to be idealized by the ideals of an Islamic state, and the camp which was accommodating. Meanwhile, the Nationalist group was also divided into two, namely secular nationalists and religious nationalists. It is this accommodationist Islamic group that is now together with religious nationalists trying to fight for Islam, not from its label but its substance.

This debate is a polemic that has never ended since BPUPKI / PPKI in 1945, the Old Order, the New Order, and even the Reformation Order. This theme reappeared through the debate on article 29 of the 1945 Constitution which took place at the MPR Annual Session. Two Islamic party factions; In the general view, the United Development Party (F-PPP) and the Bintang Bintang (F-PBB) faction insisted on re-inserting the Jakarta Charter into the body of the 1945 Constitution, particularly Article 29. They emphasized that adding seven words as in the Jakarta Charter does not mean the formation of an Islamic state.

${ }^{30}$ Kamsi, 'Paradigma Politik Islam Tentang Relasi Agama dan Negara', In Right: Jurnal Agama dan Hak Azazi Manusia 2, no. 1(2017).

${ }^{31}$ Kamsi, 'Citra Gerakan Politik Islam dalam Lintasan Sejarah Perpolitikan Bangsa Indonesia (Studi Era PRA Kemerdekan Sampai dengan Era Orde Baru)', Millah 12, no. 3 (15 August 2013): 109-52, https://doi.org/10.20885/millah.vol12.iss3.art6. 
The relationship between the state and Islam at the beginning of independence and the Old Order era is also quite interesting to discuss, the PPKI session on August 18,1945, resulted in a decision to delete the seven words in the Jakarta Charter, which subsequently became the basis for the application of Islamic law in Indonesia. In this case Moh. Hatta admitted that he was the initiator of the elimination of the seven words that had been approved by the Islamic representatives at PPKI, namely Ki Bagus Hadikusumo, KH. Wahid Hasyim, Tengku M. Hasan, and Kasman Singodimejo. The background for the writing off of the seven words was because on the afternoon of 17 August 1945, he was visited by a person from the eastern part of Indonesia who was escorted by Maeda (the military ruler in Jakarta) who asked that the seven words in the Jakarta Charter be crossed out. Because they are discriminatory, if the seven words are not crossed out, it would be better if it was not for his party to join independence with Indonesia. That is why before the PPKI session on August 18 started, Hatta asked the opinions of the four figures mentioned above. ${ }^{32}$

Historical facts during the early days of independence include, first, the existence of a dialectic between political structures and very strict rules of the game. The political structure that is very conducive to democracy has resulted in the emergence of legal rules that are supportive of the implementation of citizens' rights. Therefore, in the era of this Parliamentary Democracy regime in Indonesia, there is a very big opportunity for the democratization process. However, as we know, this kind of momentum cannot be used by our leaders so that the trial of Parliamentary Democracy disappeared after the President issued a Presidential Decree on July 5, 1959.

Second, the existence of political tension in the Constituent Assembly that has never subsided between nationalist groups and Islamic groups in the struggle for state ideology. This means that the relationship between Islam and the State has not shown a harmonious relationship or is in the form of an antagonistic relationship. According to Bachtiar Effendi's analysis, as quoted by Akhmad Satori, the condition of political dynamics in this era shows that Islamic political thoughts and practices in the past experienced gaps that were not bridged with the political ideas of nationalists. Yet these nationalists consisted partly of devout Muslims. They do not support political ideas that want to link

32 Muhsin Aseri, 'Politik Hukum Islam di Indonesia', Al Qalam: Jurnal Ilmiah Keagamaan dan Kemasyarakatan, no. March (2018), https://doi.org/10.35931/aq.v0i0.57. 
Islam with the state in a formalistic and legalistic manner. This gap in the relationship between Islam and the state was bridged in the third decade of the New Order era, as the author will explain in the discussion of the relationship between the state and Islam in the New Order era.

The relationship between the state and Islam in the New Order was no less interesting. At the beginning of the consolidation period, the romanticism of the state and Islam was built after overthrowing the old order government, those who did not like Soekarno's leadership style considered the new order an era full of hope. At the start of the New Order, there were two attempts by the Muslim community to race against other supporters of the New Order to fill it. The first is Masjumi's rehabilitation effort. Masjumi figures with their various channels fight for the immediate release of the figures who are still in detention and the Masyumi Party to be rehabilitated. In the era of the Soekarno regime in power, this party and its figures were indeed hard pressed and suffered. After disbanding, their votes were still collected informally and on 24 October 1966 in front of the big family of Bulan Bintang, Prawoto Mangkusasmito, the general chairman of the party when it was dissolved, made a speech about the party's rehabilitation, even though he was aware that the request would not be easily granted. because there are still objections within ABRI and this can be felt in his speech, but he is still excited because there are various supports. ${ }^{33}$

This optimism faded after ABRI's statement in December 1966. At that time ABRI stated that the PKI and Masyumi forbidden parties were parties that had corrupted Pancasila and the 1945 Constitution. Prawoto sent a letter to the Chairman of the Cabinet Presidium, General Soeharto on 22 December 1966, expressing his feeling objections to the status of Masyumi who disbanded (not dissolved) was equated with the PKI. The letter was answered by General Soeharto on January 6, 1967, in point number 7 it was stated that "juridical, constitutional and psychological reasons have led ABRI to a conviction that ABRI cannot accept the rehabilitation of the former Masyumi political party." However, the political rights of Masjumi members are guaranteed. ${ }^{34}$

33 Muhammad Zulifan, 'Politik Islam di Indonesia: Ideologi, Transformasi dan Prospek dalam Proses Politik Terkini', Politik Indonesia: Indonesian Political Science Review 1, no. 2 (2016): 171-95, https://doi.org/10.15294/jpi.v1i2.6583.

34 Zulifan, 187. 
The second attempt by Muslims at the beginning of the New Order was seen in the efforts of the first Vice President of Indonesia, Mohammad Hatta in 1966/67 to establish the Indonesian Islamic Democratic Movement, together with the younger generation of Muslims who were generally not politically active during the Parliamentary Democracy and Guided Democracy. It means that after three months this movement will become a party. This effort was also not justified by the President. Initially, BKAM wanted to work with Hatta in establishing a party. However, due to different perceptions, namely Hatta, as in 1930, wanted to build a cadre party, while BKAM received a lot of support from community organizations. ${ }^{35}$

So that the political upheaval of Islamic politics during the New Order era also increased, even though at the beginning it carried out sympathetic politics to the Masyumi by releasing some former Masjumi figures who were imprisoned by the Soekarno regime, but the New Order regime refused to fulfill the demands of Masyumi figures to carry out rehabilitation for Masyumi. This rejection was also strengthened by army officers and intellectual reformers as well as people in Suharto's circle who were not sympathetic to Islamic groups.

This rejection was based on the New Order's fear of the rise of Islamic political power. Besides, Masjumi's involvement in the regional rebellion made military groups, especially abangan generals, generally have a strong connection to Javanese cultural traditions, especially those from the Diponegoro (Central Java) and Brawijaya (East Java) Military Regional Commands. adhering to Javanese tradition, and at the beginning of the New Order it was these military officers who became Suharto's trust and close friends), led by Lieutenant General Ali Moertopo in Suharto's anti-Islamic circle who rejected Masjumi's rehabilitation. ${ }^{36}$

In short, the story related to Suharto's approach to Islam is the political reality faced at that time. According to several observers, the shift in Suharto's political attitude towards Islam raises three possibilities; First, there is government co-optation of Muslims. The government as a subject makes Muslims an object and is used for political purposes. Second, there is

35 Fikria Najitama, 'Sejarah Pergumulan Hukum Islam dan Budaya serta Implikasinya Bagi Pembangunan Hukum Islam Khas Indonesia', no. January 2007 (2018).

36 Zulifan, 'Politik Islam di Indonesia: Ideologi, Transformasi dan Prospek dalam Proses Politik Terkini'. 
government accommodation for Muslims. The government is aware of its mistakes in the past. In return, the government accommodates the interests of Muslims by approaching, embracing Muslims, and providing a proper place in the inner circle of power. Third, a form of integration of the people into the government. Here the position of the ummah is the pro-active party towards the government. Muslims as subjects integrate into the circle of power. This can also be read as the success of Muslims in making da'wah networks to penetrate the highest layers of power namely the President.

The relationship between the state and Islam during the reformation period was quite interesting, at the beginning of the reform, the relationship between the two seemed to be fluid after the euphoria of reforms which succeeded in overthrowing the New Order regime which had been in power for 32 years. Even though economically this nation was hit by a deep monetary crisis. However, the drama of confrontation by Islamic groups that offers the inclusion of seven words in the Jakarta Charter in the constitution remains a classic dynamic in the story of the relationship between the state and Islam in Indonesia.

In this era, there are two camps of political contestants, seen from their view of the relationship between state and religion, namely secularism and religion. The secular group is a fraction of the nationalist group which since the early decades of independence has been divided into two, namely the secular nationalist group and the religious-nationalist group. Meanwhile, religious groups are driven by hardline Muslims who want Indonesia to be a country with an Islamic ideology. ${ }^{37}$ Since the decade of the seventies, the secularists have also split into two camps. First, the faction that still wants ideals or political Islamic groups (Islamists) with the ideals of an Islamic state and who want the formal application of Islamic law. Second, the camp which is more accommodating or political Islam (substantive Islam) in its political perspective. ${ }^{38}$

It is this accommodationist Islamic group that is currently working together with religious nationalists to fight for Islam not from the label side but the substance. The merger of the two groups inevitably accompanies the weakness

37 Eko Eddya Supriyanto, Eksistensi Nilai-Nilai Pancasila dalam Kebijakan Ekonomi Indonesia, 1st ed. (Malang: Literasi Nusantara, 2020).

38 Lucky Nugroho et al., 'The Contribution of Islamic Bank in Poverty Alleviation', Al-Ahkam 30, no. 1 (2020): 19, https://doi.org/10.21580/ahkam.2020.30.1.5387. 
of the hardline groups and continues and runs dynamically. They continue to try to spread their influence in Indonesia.

\section{Conclusion}

The existing laws and regulations governing the life order of the community are still very limited and sometimes many things have not been reached. Therefore, through various kinds of holistic legal interpretation approaches to legal principles, it is hoped that the law will be able to answer various kinds of problems in the increasingly complex life of society.

The penetration of Islamic law into statutory regulations substantively and not explicitly stated as Islamic laws, is a model that is more in line with the spirit of the objectives of the Unitary State of the Republic of Indonesia (NKRI) as stated in the Preamble to the 1945 Constitution. Therefore, transforming the principles of Islamic law occupies a strategic position, compared to legal formalistic Islamic law demands.

Many Islamic legal principles are compatible with and have been used in Indonesian national law. There are at least three principles of the Islamic law that require further study in efforts to reform Indonesian national law, namely the principle of fahm al-mukallaf, the principle of criminal amnesty, and the principle of not retroactive.[a]

\section{BIBLIOGRAPHY}

Afdilah, Muhammad. Dari Masjid ke Panggung Politik: Melacak Akar-Akar Kekerasan Agama Antara Komunitas Sunni dan Syiah di Sampang, Jawa Timur. CRCS Universitas Gadjah Mada, 2016.

Ahmad Zuhdi. 'Perkembangan Metodologi Penelitian Hukum'. Jurnal Hukum dan Peradilan, 1, no. 2 (2012): 189-206.

Al-Alwānī, Tāhā Jābir. Source Methodology In Islamic Jurisprudence. Edited by Yusdani. Yogyakarta: UII Press, 2001.

Aseri, Muhsin. 'Politik Hukum Islam di Indonesia'. Al Qalam: Jurnal Ilmiah Keagamaan dan Kemasyarakatan, no. March (2018). https://doi.org/ 10.35931/aq.v0i0.57. 
Departemen Pendidikan Nasional. Kamus Besar Bahasa Indonesia Pusat Bahasa. Jakarta: Gramedia Pustaka Utama, 2008.

Halim, Abdul. 'Membangun Teori Politik Hukum Islam di Indonesia'. AHKAM: Jurnal Ilmu Syariah 13, no. 2 (2013): 259-70. https://doi.org/10.15408/ ajis.v13i2.938.

Hanafi, Ahmad. Asas-Asas Hukum Pidana Islam. Jakarta: Bulan Bintang, 1990.

Hasanah, Uswatun. 'Perempuan dan Hak Asasi Manusia dalam Perspektif Hukum Islam'. Jurnal Hukum \& Pembangunan 40, no. 4 (2010): 440. https://doi.org/10.21143/jhp.vol40.no4.235.

Imron, Ali. 'Transformasi Hukum Islam ke dalam Hukum Nasional Indonesia'. Jurnal Hukum dan Dinamika Masyarakat Vol.5 No.2 April 5, no. 0854 (2008)

Iryani, Eva. 'Hukum Islam, Demokrasi dan Hak Asasi Manusia'. Jurnal Ilmiah Universitas BatanghariJambi 17, no. 2 (2017): 24-31.

Jazuni. Legislasi Hukum Islam di Indonesia. Bandung: Citra Aditya Bakti, 2005.

Kamsi. 'Paradigma Politik Islam Tentang Relasi Agama dan Negara'. In Right: Jurnal Agama dan Hak Azazi Manusia 2, no. 1 (2017).

- C . 'Citra Gerakan Politik Islam dalam Lintasan Sejarah Perpolitikan Bangsa Indonesia (Studi Era PRA Kemerdekan Sampai dengan Era Orde Baru)'. Millah 12, no. 3 (15 August 2013): 109-52. https://doi.org/ 10.20885/millah.vol12.iss3.art6.

Mubarok, Jaih. 'Dinamika Pemikiran Hukum Islam di Indonesia'. Jurnal Unusia UII Yogyakarta II, no. 48 (2003).

Muhammad Siddiq Armia. 'Sumbangsih Kerajaan Muslim Indonesia dalam Pengembangan Peradilan Islam: Analisis Historical Legal Approach'. Jurnal Justicia: Jurnal Ilmu Hukum, Perundang-Undangan dan Pranata Sosial 2, no. 2 (2017): 1-16. https://jurnal.ar-raniry.ac.id/index.php/ Justisia/article/view/2653/1906.

Mulus, Andi Alma Wardi. 'Reformasi Negara Konstitusi dan Demokrasi Menurut Pemikiran Prof. Dr. Moh. Mahfud MD'. UIN Sultam Maulana Hasanuddin Banten, 2018.

Al-Na'im, Abdullahi Ahmed. Toward an Islamic Reformation: Civil Liberties, Human Rights and International Law. New York: Syracuse University Press, 1990. 
Najitama, Fikria. 'Sejarah Pergumulan Hukum Islam dan Budaya serta Implikasinya Bagi Pembangunan Hukum Islam Khas Indonesia', no. January 2007 (2018).

Norcahyono, Norcahyono. 'Problematika Sosial Penerapan Hukum Islam di Indonesia'. JURIS (Jurnal Ilmiah Syariah) 18, no. 1 (2019): 23. https://doi.org/10.31958/juris.v18i1.1399.

Nugroho, Lucky, Akhmad Amien Mastur, Harnovinsah Harnovinsah, and Widya Aryanti. 'The Contribution of Islamic Bank in Poverty Alleviation'. AlAhkam 30, no. 1 (2020): 19. https://doi.org/10.21580/ahkam. 2020.30.1.5387.

Raharjo, Sarjito. Sisi-Sisi Lain dari Hukum di Indonesia. Jakarta: Penerbit Buku Kompas, 2003.

Raharjo, Satjipto. Hukum Masyarakat dan Pembangunan. Bandung: Alumni, 1980.

Rosyid, Maskur. Implementasi Konsep Maslahat Al-Ṭüfi dalam Fatwa MUI (20052010). 1st ed. Magelang: Ngudi Ilmu, 2013.

Rosyid, Maskur, and M. Nurul Irfan. 'Reading Fatwas of MUI a Perspective of Maslahah Concept'. Syariah: Jurnal Hukum Dan Pemikiran 19, no. 1 (2 June 2019): 91-117.

Siraj, Said Aqil. Islam Sumber Inspirasi Budaya Nusantara. Jakarta: LTN NU, 2015.

Supriyanto, Eko Eddya. Eksistensi Nilai-Nilai Pancasila dalam Kebijakan Ekonomi Indonesia. 1st ed. Malang: Literasi Nusantara, 2020.

- _ - 'Kontribusi Pendidikan Pesantren Bagi Pendidikan Karakter di Indonesia'. Jurnal Pendidikan NUsantara 1, no. 1 (2020): 13-26.

Wardatun, Atun. 'Legitimasi Berlapis dan Negosiasi Dinamis pada Pembayaran Perkawinan Perspektif Pluralisme Hukum'. Al-Ahkam 28, no. 2 (2018): 147-66.

Yusriadi. 'Strategi Pembangunan Nasional Bidang Hukum Era Orde Baru (Analisis Teoritik Tentang Kebijakan dan Implikasinya terhadap Penyelenggaraan Hukum di Indonesia)'. Masalah-Masalah Hukum2, no. Januari-Maret (2000).

Zoelva, Hamdan. 'Relasi Islam, Negara, dan Pancasila dalam Perspektif Tata Hukum Indonesia'. Journal de Jure 4, no. 2 (2012): 99-112. https:// doi.org/10.18860/j-fsh.v4i2.2980.

Zulifan, Muhammad. 'Politik Islam di Indonesia: Ideologi, Transformasi dan Prospek dalam Proses Politik Terkini'. Politik Indonesia: Indonesian 
Ahmad Yani, Megawati Barthos

Political Science Review 1, no. 2 (2016): 171-95. https://doi.org/ 10.15294/jpi.v1i2.6583. 